\title{
Aspek Hygiene dan Sanitasi dalam Pengolahan dan Penyajian Makanan dan Minuman di Pesawat Terbang
}

\author{
Winny Plumeria Aqshani ${ }^{1}$, M.Fatchoelqorib ${ }^{2}$ \\ Sekolah Tinggi Penerbangan Aviasi, Jakarta Selatan \\ e-mail : fatchoel@yahoo.com
}

\begin{abstract}
ABSTRAK
Metode penelitian kualitatif yang digunakan dalam penelitian ini adalah Teori Dasar (Grand Theory) dimana hasil yang tergambar adalah salah satu faktor penting dalam aspek Keamanan dan Keselamatan Penerbangan, kajian pendukung penting yang terkait adalah penyediaan makanan dan minuman yang dihidangkan untuk penumpang pesawat selama penerbangan. salah satu yang perlu kita kaji adalah tentang keamanan makanan dan minuman yang disajikan dalam penerbangan.

Faktor keamanan pangan merupakan hal utama dan penting agar makanan dan minuman yang dikonsumsi tidak berdampak buruk dan membahayakan kesehatan penumpang. Kejadian keracunan makanan yang menimpa penumpang pada penerbangan jarak jauh (long range flight) bahkan dapat berakibat fatal hingga kematian karena terbatasnya fasilitas pengobatan yang tersedia di dalam pesawat. Terdapat beberapa regulasi yang dikeluarkan oleh badan otoritas kesehatan terkait yang khusus mengatur tentang standar keamanan pangan untuk catering penerbangan, dalam rangka menghasilkan produk makanan minuman yang aman dikonsumsi selama penerbangan.

Tulisan ini akan membahas tentang aspek hygiene dan sanitasi dalam proses pengolahan dan penyajian makanan dan minuman di pesawat terbang baik dari segi regulasi, maupun operasional di lapangan. Dengan tulisan ini diharapkan pembaca akan mendapatkan wawasan tentang standar keamanan pangan penyediaan catering pesawat terbang dan betapa ketatnya upaya operator catering penerbangan dalam memenuhi persyaratan yang mendukung aspek keamanan dan keselamatan penerbangan.
\end{abstract}

Kata Kunci : Kebersihan, kesehatan, keamanan penerbangan.

\section{ABSTRACT}

Preparation of air catering is one of many aspects in implementation of flight safety and security. Study about security of air catering is very important to understanding how to prepare proper food and beferage in flight.

Food poisones in flight case especialy for long range flight will cause fatalities for passenger who suffers because the limited of medical facilities in flight. There are some regulations concerning about the standard of security of air catering, to guide how to prepare save food and beverage consumed in flight. This journal will focus on hygiene and sanitation aspect in processing and preparing in flight catering concerning in legal aspect and field operationals aspect. Hopefully after read this journal the audiens will undertsand about how strick and complicated air catering operator in their role to meet the security and safety of flight.

Keywords : Cleanliness, Sanity, Flight Safety. 


\section{PENDAHULUAN}

Beberapa kutipan berita tentang keracunan makanan yang terjadi kepada penumpang pesawat menggambarkan betapa pentingnya peranan hiegenis dan sanitasi dalam penyiapan makanan yang akan disajikan selama penerbangan. Penumpang Keracunan Usai Makan Pancake Kedaluwarsa di Pesawat Air China Dilansir Shanghaiist, peristiwa ini terjadi pada Minggu (06/10/13) di pesawat Air China dengan nomor penerbangan CA1268 dari Xinjiang menuju Beijing, seorang balita langsung muntah setelah menyantap pancake daging sapi, kemudian 30 orang penumpang lain muntah-muntah dan diare. Antrean di depan toilet kabin pesawatpun tak terhindari sampai pesawat mendarat sekitar pukul 19:00 waktu setempat.

Keracunan Makanan di Pesawat, Penumpang Ini Gagal Liburan, Dilansir Suara.com, dari halaman The Sun pada Selasa (21/5/19), seprang wanita bernama Karen Davies berencana menuju Las Vegas untuk merayakan ulang tahunnya yang ke-40 tahun dengan penerbangan British Airways. Ketika sedang dalam perjalanan, Karen Memutuskan untuk memsan menu salad di pesawat. Ternyata salad spesial ala British
Airways yang dipesannya berjamur dan Karen terlanjur memakannya sebagian. Sayang, tiba di Hotel, Karen mulai merasa tidak enak badan dan mengalami muntah-muntah dan sakit perut pada hari pertama liburannya. Santap Nasi Lauk Cicak, Penumpang Pesawat Keracunan Dikuti dari Dream dari Malaysiandigest.com, Jumat 8 April 2016, seorang penumpang pesawat Air Asia, Abbas Waseem, keracunan setelah menyantap nasi lemak yang dihidangkan di atas pesawat. Abbas menemukan makanan yang disajikan itu tidak higienis. Ada cicak di antara lauk pauk nasi lemak itu. Gara-gara makanan itu, Waseem yang merupakan warga Pakistan itu harus dirawat di klinik kesehatan. Dia mengaku keracunan, sebab dia sempat menelan beberapa suap hidangan itu sebelum menemukan bangkai cicak dalam penerbangan 27 Maret itu.

$$
\text { Jasaboga adalah usaha }
$$
pengelolaan makanan yang disajikan di luar tempat usaha atas dasar pesanan yang dilakukan oleh perseorangan atau badan usaha. Pengelolaan makanan adalah rangkaian kegiatan yang meliputi penerimaan bahan mentah atau makanan terolah, pembuatan, pengubahan bentuk, pengemasan, pewadahan, pengangkutan dan penyajian. Tempat pengolahan makanan adalah area tempat makanan 
dipersiapkan atau dipanaskan ulang. Higiene sanitasi adalah upaya untuk mengendalikan faktor risiko terjadinya kontaminasi terhadap makanan, baik yang berasal dari bahan makanan, orang, tempat dan peralatan agar aman dikonsumsi, Penjamah makanan adalah orang yang secara langsung mengelola makanan, dan hal yang berhubungan dengan makanan yang harus mengikuti persyaratan yang berlaku, Pembersihan adalah proses penghilangan tanah, residu makanan, debu, minyak atau bahan yang tidak sesuai lainnya, Kontaminasi adalah keberadaan benda lain yang ada di produk yang dapat menyebabkan makanan tercemar, Disinfeksi adalah pengurangan, tanpa mengganggu makanan dengan cara higienis menggunakan kimia atau metode fisik, dari jumlah mikro-organisme tingkat bahaya ke tingkat yang tidak akan menyebabkan kontaminasi berbahaya dari makanan. Hama adalah serangga, burung, tikus dan hewan lain yang dapat secara langsung atau tidak langsung mengkontaminasi makanan, Bahan kemasan makanan adalah setiap wadah seperti kaleng, botol, karton, kotak, peti dan karung, atau membungkus dan menutupi material seperti kertas, film, logam, kertas, kertas lilin kain, dll., Portioning adalah pembagian makanan sebelum atau setelah memasak menjadi tunggal atau beberapa bagian, Penyusunan Makanan (meal assembly) adalah menyusun atau menempatkan makanan untuk individu dalam atau pada suatu wadah yang sesuai, di mana akan disimpan sampai pengiriman ke konsumen. Makanan berpotensi tinggi/bahaya - MBT (potentially hazardous food) adalah makanan yang mampu mendukung pertumbuhan yang cepat dan progresif mikroorganisme penghasil racun dan dapat menyebabkan infeksi.

Enam Prinsip Higiene Sanitasi Pangan antara lain 1) Pemilihan bahan baku makanan yaitu Perlindungan terhadap bahan baku dari bahaya-bahaya bahan kimia atau pertumbuhan mikroorganisme patogen dan pembentukan toksin selama transportasi dan penyimpanan bahan baku mutlak diperhatikan. Bahan-bahan yang dimakan dalam keadaan mentah harus diangkut dan disimpan terpisah dari bahan baku lain dan bahan-bahan yang bukan bahan pangan, Bahan pangan harus dikirim sedemikian rupa sehingga mencegah pertumbuhan mikroorganisme patogen atau pembentukan toksin dengan mengatur lamanya waktu pengiriman, suhu dan aktifitas air (water activity=Aw) bahan baku. Penyimpanan bahan makanan; Kerusakan bahan makan dapat terjadi karena tercemar bakteri, karena alam dan perlakuan manusia, adanya enzim dalam 
makanan yang diperlukan dalam proses pematangan seperti pada buah-buahan dan kerusakan mekanis seperti gesekan, tekanan, benturan dan lain-lain, Untuk mencegah terjadinya kerusakan dapat dikendalikan dengan pencegahan pencemaran bakteri.

Sifat dan karakteristik bakteri seperti sifat hidupnya, daya tahan panas, faktor lingkungan hidup, kebutuhan oksigen dan berdasarkan pertumbuhannya, Terdapat empat cara penyimpanan makanan sesuai dengan suhu yang dipersyaratkan, yaitu penyimpanan sejuk (cooling), penyimpanan dingin (chilling), penyimpanan dingin sekali (freezing), penyimpanan beku (frozen). 3) Pengolahan makanan; Pengolahan makanan adalah proses pengubahan bentuk dari bahan mentah menjadi makanan yang siap santap dan Pengolahan makanan yang baik adalah yang mengikuti kaidah dan prinsipprinsip hygiene dan sanitasi. 4) Pengangkutan makanan; Pengangkutan makanan yang sehat akan sangat berperan dalam mencegah terjadinya pencemaran makanan, dan pencemaran pada makanan masak lebih tinggi risikonya daripada pencemaran bahan makanan. Oleh karena itu titik berat pengendalian yang perlu diperhatikan adalah pada makanan masak. 5) Penyimpanan makanan; Bakteri akan tumbuh dan berkembang dalam makanan yang berada dalam suasana yang cocok untuk hidupnya sehingga jumlahnya menjadi banyak, Suasana yang cocok untuk pertumbuhan bakteri di antaranya suasana makanan banyak protein dan banyak air (moisture), $\mathrm{pH}$ normal (6,8$7,5)$, suhu optimum $\left(10^{\circ}-60^{\circ} \mathrm{C}\right)$, Bahaya terbesar dalam makanan masak adalah adanya mikroorganisme patogen dalam makanan akibat terkontaminasinya makanan sewaktu proses pengolahan makanan maupun kontaminasi silang melalui wadah maupun penjamah. makanan, kemudian dibiarkan dingin pada suhu ruangan, Kondisi optimum mikroorganisme patogen dalam makanan siap saji ini akan mengakibatkan mikroorganisme berlipat ganda dalam jangka waktu antara 1-2 jam, Faktor risiko pada kejadianfoodborne diseases yaitu pada proses pembersihan alat makan kontak dengan makanan, dan Faktor risiko juga dapat disebabkan oleh temperatur dan waktu penyimpanan tidak baik, rendahnya personal hygiene, dan alat makan yang terkontaminasi.

Penyajian makanan; Makanan yang disajikan adalah makanan yang siap santap/layak santap. Layak santap dapat dinyatakan bilamana telah dilakukan uji organoleptik dan uji biologis dan Dalam prinsip penyajian makanan wadah untuk setiap jenis makanan ditempatkan dalam 
wadah terpisah, dan diusahakan tertutup. Tujuannya agar makanan tidak terkontaminasi silang, bila satu makanan tercemar yang lain dapat diselamatkan, serta memperpanjang masa saji makanan sesuai dengan tingkat kerawanan pangan. Tujuan Higiene dan Sanitasi ; 1) Terlaksananya Pengelolaan higiene sanitasi pangan di seluruh Tempat Pengelolaan Makanan, 2) Terlaksananya Pengendalian Faktor Risiko Penyakit Bawaan Pangan dan KLB Keracunan Pangan di Seluruh Sasaran Tempat Pengelolaan Makanan, dan 3) Terlaksananya Survailans Epidemiologi faktor risiko penyakit bawaan pangan di seluruh Tempat Pengelolaan Pangan.

\section{Dasar Hukum Penyelenggaraan} Higiene dan Sanitasi Undang-Undang No. 18 tahun 2012 tentang Pangan Pasal 70; (1) sanitasi pangan dilakukan agar pangan aman untuk dikonsumsi; (2) sanitasi pangan dilakukan dalam kegiatan atau proses produksi, penyimpanan, pengangkutan, dan/atau peredaran pangan, Pasal 71; (1) Setiap orang yang terlibat dalam rantai pangan wajib mengendalikan risiko bahaya pada pangan, baik yang berasal dari bahan, peralatan, sarana produksi, maupun dari perseorangan sehingga keamanan pangan terjamin. (2) Setiap orang yang menyelenggarakan kegiatan atau proses produksi, penyimpanan, pengangkutan, dan/atau peredaran pangan wajib: Memenuhi persyaratan sanitasi; dan Menjamin keamanan pangan dan/atau keselamatan manusia. Undang-Undang No. 36 tahun 2009 tentang Kesehatan Pasal 111 (ayat 1) makanan dan minuman yang dipergunakan untuk masyarakat harus didasarkan pada standar dan/atau persyaratan kesehatan, Pasal 163 (ayat 3); Lingkungan sehat berarti bebas dari unsur-unsur yang menimbulkan gangguan kesehatan, antara lain: limbah cair; limbah padat; limbah gas; sampah yang tidak diproses sesuai dengan persyaratan yang ditetapkan pemerintah; binatang pembawa penyakit; zat kimia yang berbahaya; kebisingan yang melebihi ambang batas; radiasi sinar pengion dan non pengion; air yang tercemar; udara yang tercemar; dan makanan yang terkontaminasi.

Peraturan Pemerintah Nomor 28 Tahun 2004 Tentang Keamanan, Mutu dan Gizi Pangan, Pasal 2 ; (1) Setiap orang yang bertanggung jawab dalam penyelenggaraan kegiatan pada rantai pangan yang meliputi proses produksi, penyimpanan, pengangkutan, dan peredaran pangan wajib memenuhi persyaratan sanitasi. (2) Persyaratan sanitasi diatur lebih lanjut oleh Menteri yang bertanggung jawab di bidang kesehatan yang meliputi antara lain : a. 
sarana dan/atau prasarana, b. melihat gambaran kasus secara global di penyelenggaraan kegiatan; dan c. orang atas.

perorangan. Pasal 3; Pemenuhan standar sanitasi di seluruh kegiatan rantai pangan dilakukan dengan cara menerapkan pedoman cara yang baik meliputi: a. Cara Budidaya yang baik; b. Cara Produksi Pangan Segar yang baik; c. Cara Produksi Pangan Olahan yang baik. d. Cara Distribusi Pangan yang baik; e. Cara Ritel Pangan yang baik; dan f. Cara Produksi Pangan Siap Saji. Permenkes No. 2 Tahun 2013 Tentang KLB Keracunan Pangan; Pasal 1; (4) Suatu kejadian dimana terdapat dua orang atau lebih yang menderita sakit dengan gejala yang sama atau hampir sama setelah mengkonsumsi pangan dan berdasarkan analisis epidemiologi pangan tersebut terbukti sebagai sumber keracunan.

Dalam latar belakang telah disampaikan mengenai contoh kasus kejadian berkaitan dengan Hygiene dan Sanitasi, disini terlihat adanya suatu kesalahan yang terjadi dalam menyajikan, atau memberikan suatu hidangan kepada penumpang yang berakibat fatal. Melihat dari aspek peraturan yang ada di Indonesia maka akan coba dibahas mengenai keterpenuhan dari pihak pemilik pesawat terbang atau airlines dari sisi peraturan, apakah terpenuhi atau tidak dengan

\section{METODE PENELITIAN}

Dalam menulis penelitian ini metode yang digunakan adalah metode penelitian kualitatif dengan menggunakan metode Teori Dasar (Grounded Theory). Data yang ada dalam penelitian ini adalah melihat fenomena kejadian-kejadian yang berkaitan dengan Hygiene dan Sanitasi dalam menyajikan makanan di pesawat terbang.

Data yang ada dalam kasus di atas yang terjadi secara global akan dikaji dengan dasar legalitas yang ada di Indonesia dimana perusahaan penerbangan di Indonesia apakah sudah memenuhi aspek-aspek yang ada dalam peraturan dan apakah ada kejadian dari sisi Hygiene dan Sanitasi di Indonesia.

\section{PEMBAHASAN}

Penunjang pengelolaan pangan untuk penumpang pesawat terbang; Desain dan Fasilitas, Desain dan fasilitas ini meliputi area dimana makanan yang disiapkan, dimasak, didinginkan, dibekukan dan disimpan, yaitu: 1) Lokasi Catering, Lokasi tidak berdekatan dengan sumber pencemaran seperti tempat sampah umum, WC umum, pabrik cat, area banjir, semak-semak, persawahan, rawa, daerah peternakan, tempat pembuangan sampah dan sumber pencemaran lainnya. Apabila tidak dimungkinkan maka harus dilakukan tindakan yang dapat meminimalisasi 
bahaya pencemaran dan lokasi juga tidak berada di tempat yang mudah banjir, dan terbebas dari kemungkinan pencemaran udara seperti debu/kotoran yang beterbangan, bau menyengat dan hama; 2) Zoning; 3) Red Zone, area produksi dimana dipersyaratkan untuk menggunakan pakaian kerja khusus produksi, sepatu khusus produksi (sepatu yang hanya digunakan di area produksi, tidak diperkenankan dibawa pulang), penutup rambut (hair net, bagi yang berjilbab agar mengganti jilbab khusus produksi (bergo tanpa aksesoris)), penutup mulut (masker), tidak menggunakan aksesoris (jam tangan, cincin, anting dan perhiasan lainnya kecuali cincin kawin yang tidak bermata) dan menggunakan sarung tangan bila sedang menangani makanan jadi (ready to eat food).

4) Yellow Zone, area non kitchen (receiving, store, equipment dan standard set up, loading dan off loading, laundry, dishwashing, area produksi kantin karyawan, dimana dipersyaratkan untuk menggunakan pakaian kerja, menggunakan penutup rambut, tidak menggunakan aksesoris (jam tangan, cincin, anting, dan perhiasan lainnya kecuali cincin kawin yang tidak bermata) dan menggunakan sarung tangan apabila saat menangani peralatan bersih. Sepatu menggunakan jenis sepatu tertutup; 5) Green Zone, area office dan administrasi. Dimana ruangan yang tidak bersentuhan dengan makanan baik mentah maupun siap saji sehingga tidak diperlukannya perlakuan khusus; 6) Fasilitas Air Bersih, Kualitas air bersih/air minum harus memenuhi persyaratan sesuai dengan peraturan yang berlaku yang dikeluarkan oleh Departemen Kesehatan, Setiap hari air dimonitor dengan pengecekan secara visual terhadap warna, bau, kejernihan dan pengujian kadar desinfektan (contoh menggunakan klorin) pada air tersebut; 7) Fasilitas Penyimpanan Produk, Terdapat fasilitas penyimpan material dimana sudah dapat dipisahkan antara raw material dengan ready to eat dan bahan tersertifikasi dan non tersertifikasi halal. Penyimpanan produk disesuaian dengan spesifikasi produk. Tersedia fasilitas pendingin baik chiller maupun freezer yang disesuaikan dengan jumlah yang cukup untuk menyimpan bahan makanan dan makanan jadi (ready to eat) sehingga dapat menghindari terjadinya potensi kontaminasi silang. Suhu chiller dan freezer sesuai dengan yang dipersyaratkan. Tersedia fasilitas untuk mendinginkan makanan secara cepat. Terdapat alat monitoring pemantauan suhu yang cukup dan layak digunakan (terkalibrasi dan terverifikasi; 8) Fasilitas Toilet, Harus menyediakan dan memastikan bahwa toilet, ruang ganti pakaian kerja dan loker senantiasa bersih dan terpelihara dengan baik. Fasilitas toilet harus ditempatkan pada jarak yang cukup/tidak berdekatan dengan ruang produksi, 9) Fasilitas Mencuci Tangan, Tersedia tempat cuci tangan/wastafel selalu tersedia di tempat-tempat yang membutuhkan fasilitas tersebut seperti : a) Area akan memasuki ruang produksi, b) Area di dalam ruang produksi, c) Receiving, d) Toilet, e) Area-area lain yang dipandang perlu, Fasilitas pencucian tangan seharusnya selalu dilengkapi 
dengan foot operates (buka tutup dengan kaki) dan sabun yang mengandung antiseptik; 10) Fasilitas Pencucian dan Sanitasi Peralatan, Tersedianya fasilitas untuk pembersihan dan sanitasi alat kerja yang dibangun dari bahan tahan korosi dan mudah untuk dibersihkan Dilengkapi dengan fasilitas air panas dan dingin yang cukup, Apabila dilakukan secara manual, tidak menggunakan mesin, maka pencucian seharusnya menyediakan 3 bak pencuci, yaitu tempat pencucian, pembilasan dan pemberian sanitasi. Dan harus dilakukan validasi dengan pengujian laboratorium minimal setiap 3 bulan; 11) Fasilitas Pengolahan Limbah, Saluran pembuangan limbah harus dibuat secara tepat lokasinya dan berfungsi dengan baik, sehingga tidak memungkinkan terjadinya genangan air di saluran. Limbah gas diatur dan diolah sedemikian rupa sehingga tidak mengganggu kesehatan karyawan dan tidak menimbulkan pencemaran lingkungan. Limbah cair diolah terlebih dahulu sebelum dialirkan ke lingkungan. Hasil pengolahan limbah cair sudah memenuhi persyaratan lingkungan sebelum dibuang ke saluran drainase, Limbah padat harus dilakukan penanganan sehingga tidak menimbulkan permasalahan lingkungan, dan Limbah tidak dibiarkan menumpuk di halaman luar, tempat pengolahan makanan, ruang penyimpanan, dan ruang lainnya, dan segera ditangani, diolah dan/atau dibuang. 9)

Pengendalian Hama (Pest Control), Terdapat program yang berkelanjutan dan efektif untuk pengendalian hama dan secara regular dilakukan untuk memastikan area pengolahan makanan terbebas dari hama. Program kerja minimal harus mencakup : a) Jadwal kegiatan kunjungan dalam rangka pengendalian serangga yang mencakup nama staff pelaksana lapangan dan tanggal kunjungan, b) Identifikasi jenis hama yang berada di area gedung c) Jenis bahan kimia dan konsentrasi yang digunakan untuk membasmi hama yang telah diidentifikasi d) Metode kerja yang dilakukan sesuai dengan jenis serangga, jenis bahan kimia yang digunakan, e) Peta perangkap hama (serangga, rodent/tikus) di seluruh area gedung, f) Dokumentasi hasil pekerjaan (checklist) sesuai dengan jadwal yang telah dibuat. Persyaratan Kesehatan Karyawan dan Hygiene Personil ; 1) Pelatihan/Training, Semua karyawan wajib mendapatkan pelatihan hygiene sanitation/food safety minimal satu tahun sekali serta didokumentasikan dengan baik, baik materi yang disampaikan maupun daftar kehadiran peserta pelatihan. Kegiatan pelatihan tersebut harus dijadwalkan secara tertulis untuk semua karyawan. Dan Kegiatan pelatihan harus dievaluasi dan di dokumentasikan dengan baik; 2) Medical Screening, Rectal Swab, Penyakit Menular, dan Luka, Diwajibkan memeriksakan kesehatan karyawan bagian produksi secara periodik (minimal satu tahun sekali) ke dinas / lembaga kesehatan setempat, terutama berkaitan dengan jenis penyakit yang sifatnya menular \& menahun. Jenis pemeriksaan meliputi: a) Pemeriksaan paru-paru (penyakit TBC), Pemeriksaan hepatitis A dan B, b) Pemeriksaan salmonella, c) Pemeriksaan 
cholera; d) Pemeriksaan typoid, Diwajibkan memeriksa rectal swab untuk penjamah makanan secara periodik minimal 2 kali dalam setahun. Jenis pemeriksaan meliputi: a) coli patogen; b) Salmonella, Menindaklanjuti hasil pemeriksaan karyawan yang menunjukkan gejala-gejala penyakit tersebut dengan mengobatinya dan memindahkan sementara karyawan tersebut di area yang tidak berhubungan dengan kontak makanan/ peralatan secara langsung yang dapat menimbulkan potensi kontaminasi silang.

Apabila diketahui adanya wabah penyakit menular di lingkungan perusahaan, agar dapat ditangani sesuai dengan standard / undangundang yang berlaku di wilayah tersebut meliputi langkah pencegahan penyebaran, langkah pemutusan wabah dan pengaruh terhadap kondisi pengolahan makanan. Diwajibkan menyediakan kotak P3K (first aid box) dilengkapi dengan checklist item obat dengan tanggal kadaluarsanya sebagai pertolongan pertama bagi karyawan ketika terjadi kecelakaan kerja. Karyawan yang mengalami pendarahan pada saat terjadi kecelakaan kerja dan dapat menimbulkan potensi kontaminasi silang pada makanan tidak diperbolehkan melanjutkan kerja, terutama yang behubungan dengan kontak makanan/peralatan langsung. Permasalahan Pangan ; 1) Bahaya Kontaminasi Silang, Bahan makanan mentah, peralatan yang kotor dan karyawan merupakan sumber bakteri patogen yang dapat mengkontaminasi silang. Berikut beberapa hal mengenai pencegahan terhadap berbagai potensi bahaya, 2) Bahaya Fisik, Sebaiknya semua bahan baku yang bersifat halus / tepung dilakukan proses penyaringan (shifting) sebelum digunakan. Hal ini untuk mengantisipasi adanya kemungkinan serpihan kemasan atau bahan baku padatan lainnya yang terbawa di tepung, Pemecahan telur tidak berada dekat dengan makanan matang. Proses pemecahan minimal menggunakan dua wadah untuk menghindari potensi telur rusak/busuk tercampur. Terakhir sebelum digunakan, telur harus dilakukan penyaringan untuk memisahkan adanya kulit telur atau kotoran lainnya yang terbawa, Dilarang memakai gelas / peralatan dari kaca serta kayu di area produksi dan area lainnya yang memungkinkan adanya potensi kontaminasi langsung (contoh area produksi/ pembuatan es batu (ice cubes) ; a) Dilarang menyimpan/meletakkan peralatan gelas di area makanan terbuka; b) Tidak diperkanankan memakai peniti atau hiasan di area produksi; c) Tidak diperkenankan penggunaan stapler terutama di area produksi; d) Tidak diperkenankan penggunaan pisau yang mudah patah seperti cutter; e) Tidak diperkenankan peralatan dari kayu; f) Tidak diperkenankan penggunaan alat tulis seperti bolpoint, pensil dan lain-lain yang mengggunakan tutup terpisah; g) Tidak diperkenankan merokok di area produksi; h) Pastikan bahwa alat dan peralatan dalam keadaan baik (tidak patah, pecah, gompal dan terkelupas), dan Hal lainlain yang menyebabkan kontaminasi bahaya fisik. 
Bahaya Kimia, Ruangan bahan kimia terpisah dan terkunci serta hanya yang berwenang dan terlatih dalam menangani bahan kimia tersebut, Bahan kimia disimpan jauh dari makanan dan minuman, Tidak menuangkan bahan kimia pada bahan tempat / bekas makanan, semua wadah bahan kimia harus diberi label dengan jelas, dan tersedianya MSDS untuk semua bahan kimia yang digunakan. Bahaya Mikrobiologi, Penggunaan warna cutting board yang berbeda, sebagai berikut ; Biru untuk bahan mentah dari ikan dan seafood, Kuning untuk bahan mentah unggas, Merah untuk bahan mentah daging, Hijau untuk sayuran dan buah, dan Putih untuk makanan olahan matang. Apabila kondisi perusahaan tidak memungkinkan untuk menggunakan jenis cutting board warna, maka dapat dilakukan identifikasi lain seperti identifikasi nama dan lainnya yang dapat memastikan tidak adanya pemakaian cutting board yang berganti-ganti antara satu jenis bahan makanan dengan yang lainnya. Tidak menyentuh bahan makanan secara langsung pada saat menangani makanan, menggunakan sarung tangan atau penjepit. Pastikan peralatan yang digunakan untuk bahan mentah dan matang terpisah, Pastikan pisau setelah digunakan direndam pada larutan sanitasi sebelum digunakan untuk mengolah makanan yang lain, Pastikan memegang equipment (gelas, piring, sendok dll) bersih dengan menggunakan sarung tangan (hand glove), Penyimpanan bahan makanan mentah atau belum dicuci dipisahkan dengan produk matang atau yang sudah disanitasi, Area persiapan (preparation) seharusnya terpisah antara persiapan daging/ikan mentah, persiapan buah dan sayuran, Semua peralatan untuk pengolahan makanan harus dibersihkan dan disanitasi terlebih dahulu sebelum digunakan, Permukaan kerja yang kontak dengan tangan dan makanan harus secara rutin dibersihkan dan disanitasi, Pastikan mencuci tangan ketika akan menangani makanan dan berpindah melakukan persiapan makanan yang lain, Makanan yang telah masak harus senantiasa ditutup untuk menghindari terjadinya kontaminasi silang, dan Peralatan dan perlengkapan yang digunakan untuk penanganan makanan harus bersih dan disanitasi. Sanitasi dapat menggunakan sabun antiseptik maupun bahan kimia yang mengandung antiseptik.

Keracunan pangan, Kasus keracunan makanan merupakan gambaran hitam bagi sebuah inflight catering dan merupakan hal yang paling tidak diinginkan terjadi, Untuk menghindari kasus tersebut, Inflight Catering menerapkan Prosedur Analisis Bahaya (HACCP Plan) yang merupakan kunci sistem manajemen keamanan pangan yang efektif untuk menetapkan tindakan pengendalian yang efektif. Inflight Catering biasanya akan menetapkan beberapa titik kontrol kritis dari gambaran besar alur proses produksinya. Titiktitik kontrol kritis itulah yang selanjutnya akan dilakukan monitoring khusus dengan frekuensi yang ditentukan sehingga diharapkan potensipotensi bahaya yang menuju kepada keracunan makanan tidak terjadi. IFSA juga mengatur jenis makanan yang diberikan kepada awal 
kabin serta awak cockpit untuk menghindari terjadinya keracunan makanan yang dapat mengganggu aspek keamanan penerbangan. Diberikan makanan dengan menu yang berbeda untuk awak cockpit untuk mendukung hal tersebut.

Kerjasama dengan penyedia pihak ketiga, Kerjasama dengan penyedia di luar inflight catering harus memastikan bahwa proses, produk dan jasa yang disediakan penyedia eksternal tidak berpengaruh dan merugikan citra perusahaan kepada pelanggan, Inflight Catering harus menetapkan dan memastikan bahwa semua produk yang dibeli sesuai dengan persyaratan yang ditentukan. Proses pembelian diatur sesuai dengan ketentuan yang telah diputuskan oleh Direksi. Melakukan penilaian dan memilih calon pemasok berdasarkan kemampuan pemasok untuk memenuhi permintaan secara kontinu, kesesuaian dengan spesifikasi, mutu, halal, harga dan juga mempertimbangkan faktor keamanan pangan. Perusahaan juga melakukan penilaian terhadap pemasok secara berkala termasuk kunjungan ke area produksi dari pemasok untuk barang yang berkaitan langsung dengan mutu dan keamanan pangan. Rekaman data dari penilaian dan tindakan yang timbul guna perbaikan kinerja pemasok disimpan dan dipelihara. Informasi pembelian / pengadaan barang atau jasa harus meliputi ; a) Penjelasan produk yang akan dibeli seperti jumlah, ukuran, warna, dan lainnya; b) Persyaratan persetujuan untuk pembelian produk, prosedur, proses produksi, juga peralatan yang digunakan, c) Persyaratan kualifikasi personel dari pemasok dan d) Persyaratan dari sistem manajemen mutu, halal dan keamanan pangan. Verifikasi Produk yang dibeli Guna menjamin dan memastikan Inflight Catering harus menetapkan untuk melakukan inspeksi atau kegiatan lain yang diperlukan terhadap pemasok. Pada saat akan melakukan inspeksi atau verifikasi di tempat pemasok, Inflight Catering terlebih dahulu mengkomunikasikannya kepada pemasok dan ketentuan ini merupakan bagian dari proses pembelian yang dinyatakan dalam dokumen pembelian.

\section{KESIMPULAN}

Jurnal ini memaparkan tentang aspekaspek hygiene-sanitasi yang harus dijunjung tinggi oleh sebuah Inflight Catering demi mendukung aspek keamanan penerbangan dan menghasilkan produk makanan-minuman yang baik dan aman dikonsumsi oleh penumpang pesawat.

Tahap utama hygiene-sanitasi harus diterapkan pada proses produksi inti dari makanan oleh Inflight Catering, dimulai dari penerimaan bahan baku, penyimpanan, pemasakan, pendinginan, dan persiapan pengemasan, selanjutnya menerapkan titik kontrol kritis dari tahaptahap tersebut untuk mempermudah 
monitoringnya hal lain sebagai pendukung adalah persyaratan bangunan, desain dan fasilitas, persyaratan karyawan termasuk juga pemeriksaan kesehatan periodik.

Gambaran dari peraturan-peraturan yang ada dan pemberlakuan di dalam pesawat terbang di Indonesia, dijalankan sesuai dan belum ada kejadian yang seperti digambarkan dalam kasus global yang melanggar aspek-aspek dari sisi peraturan undang-undang maupun peraturanperaturan menteri berkaitan dengan hygiene dan sanitasi.

\section{DAFTAR PUSTAKA}

Depkes RI. Penyehatan Makanan Dan Minuman, 1999.

Mahmud Yunus. 2015 Higiene Sanitasi Pangan. Workshop Peringatan Hari
Gizi Nasional (HGN) Ke-55, Jakarta : 24 Februari 2015. Hal. 3-15.

Purawidjaja, Enam Prinsip Dasar Penyediaan Makan Di Hotel, Restoran Dan Jasaboga, 1995.

QSAI Food Processing Safety Ver. 10.0. 01 Jan 2019 Standards \& Interpretation Guidelines.

World Food Safety Guidelines for Airline Catering; $\quad 4^{\text {th }}$ version, 2016; International Flight Services Association (IFSA)

https://www.dream.co.id/news/santapnasi-lauk-cicak-penumpang-airasia-keracunan160408w.html

https://food.detik.com/berita-boga/d2382864/penumpang-keracunan-usai-makanpancake-kedaluwarsa-di-pesawat-air-china https://www.suara.com/lifestyle/2019/05/ 21/084203/keracunan-makanan-di-pesawatpenumpang-ini-gagal-liburan 